\title{
Business Development Capability: Insights from the Biotechnology Industry
}

\author{
Valeria Lorenzi ${ }^{*}$,Hans Eibe Sфrensen ${ }^{* *}$
}

\begin{abstract}
Business development tasks and processes serves to improve firms' innovation efforts. Such business development activities are found and refined in the biotechnology industry, but have received remarkable little attention in the academic literature. The aim of this paper is to explore the organization of business development on the basis of existing empirical literature and three case studies from the biotechnology industry. We adopt the dynamic capabilities perspective to create a theoretical framework for building a business development capability that may serve as a source of competitive advantage. Managerial implications are discussed.
\end{abstract}

Keywords: Business Development; Business Development Function; Dynamic Capabilities; Biotechnology Industry; Opportunity Identification

\section{Introduction}

Sound management of innovation tasks and processes is taking a new and important direction: the Business Development capability (Davis, Sun 2006; Sørensen 2012). But let us set the scene first. The biotechnology industry faces high levels of scientific and technological complexity along with long lasting and very uncertain $R \& D$ processes. Such a context requires companies to balance their technological foundation with an 'outside-in' thinking process (Day 1998; Brondoni 2007; Sciarelli 2008), commonly known as market-oriented management. This market approach stimulates firms to continuously explore the market in order to identify new business opportunities and adapt their strategies to changing conditions (Lambin 2008, Vallini, Simoni 2009; Doz et al. 2001). It follows that organizations able to timely monitor information derived from the outside, have a greater aptness to perform "before and better than competitors" (Brondoni 2008) in the identification of new businesses. At the same time, firms need to maintain a high level of innovation, risk taking and proactive orientation. Some firms in high-

\footnotetext{
${ }^{*}$ Lecturer in Marketing and Innovation, University of Pavia (valeria.lorenzi@eco.unipv.it)

**Associate Professor in Business Development, University of Southern Denmark (hes@ sam.sdu.dk)

Edited by: ISTEI - University of Milan-Bicocca

ISSN: 1593-0319

Lorenzi Valeria, Sørensen Hans Eibe (2014) Business Development Capability: Insights from the Biotechnology Industry, Symphonya. Emerging Issues in Management (symphonya.unimib.it), n. 2, pp. $45-60$.
}

http://dx.doi.org/10.4468/2014.2.05lorenzi.sorensen 
tech industries are now beginning to perform a set of particular 'Business Development' activities to support identification and management of new business opportunities.

From a managerial and competitive perspective, a recent research by Davis and Sun (2006), points to Business Development as a corporate entrepreneurial capability. It is well known that strong organizational capabilities may be important sources of competitive advantage as they are difficult for competitors to imitate (Amit, Schoemaker 2006). In the management literature, a number of theoretical perspectives offer insights on what capabilities are (Winter 2003) and how firms might develop organizational capabilities. For example, the resource based view (Wernerfelt 1984; Barney 1991) focuses on the possession of resources and capabilities that are stable and enduring sources of competitive advantage.

A particular focus on identifying superior firm-specific capabilities and their development and deployment is found in the dynamic capabilities literature (Teece et al. 1997; Eisenhardt 1989; D'Aveni 1994; Eisenhardt, Martin 2000; Teece 2007). This perspective stresses the need for exploiting internal and external capabilities to address changing environments. In the corporate entrepreneurship literature emphasize capabilities residing in the firm's tendency to depart from established practices (Lumpkin, Dess 1996; Jantunen et al. 2005). The theoretical perspective of this paper thus points out that competitive advantage does not only stem from valuable, rare, difficult to imitate, but also from how they are configured and organized by managers. See for example the VRIO framework by Barney and Hesterly (2012). According to both seminal and recent works, (e.g. Chandler 1992; Dosi et al. 2000; Coriat, Dosi 2009) organizational capability in a specific business function can thus be created through the implementation of specific managerial and organizational aspects. The three main elements are:

- how to properly structure an organizational function (structure);

- $\quad$ which activities should be carried out and how (tasks and process);

- what kind of people are more adapt to be responsible for the specific set of activities (people).

Figure 1: The Main Elements of a Dynamic Organizational Capability

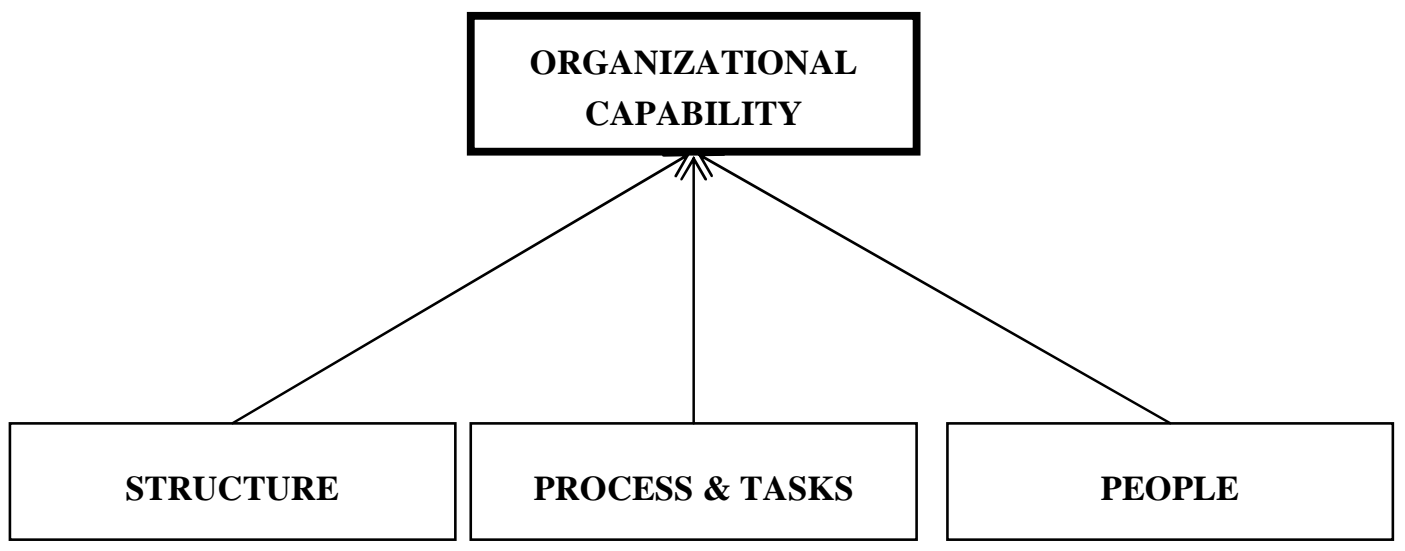

Consistently with this view, we advance that dynamic capabilities constitute an ideal approach to study the specific phenomenon of Business Development. We 
therefore propose the theoretical framework presented in Figure 1 to explore the main elements of a Business Development capability.

\section{Business Development: Conceptual Background}

Although the term Business Development is well known among young and mature enterprises (often with individual interpretations in the minds of various practitioners), the concept has up to now received little attention in the managerial and academic literature. We advise, however, to be careful with the terminology. For example, Sørensen (2013) report that 'business development' has been applied in relation to the outcome of corporate venturing (Burgelman 2002; Covin, Miles 2007; Kanter 1986; Keil et al. 2008), discrete projects (McGrath 2001; Burgers et al. 2008) as well as the organization of radical innovation (O'Connor, DeMartino 2006). Anecdotally from practice, we observe for example, a current tendency to re-label 'Sales' to 'Business Development' - apparently because of the bad connotations associated with the sales function. Despite the labelling, we will argue that neither of these selected examples are Business Development, as they diverge ontologically and may also already represent well-established phenomena. To address these issues, a small, but growing, group of scholars are now researching the unique aspects of Business Development.

The Business Development concept has been gradually delineated and clarified as a distinct notion distinct from other established management concepts (Sørensen 2012; Austin 2008; Giglierano et al. 2011; Uittenbogaard et al. 2005; Davis, Sun 2006). In particular, Davis and Sun (2006) conducted an exploratory study involving a survey of 26 IT SMEs in Canada and confirmed also in this context that Business Development was a recognized concept with distinct functions and tasks. Their research also addressed Business Development as a set of "routines and skills that serves to enable growth by identifying opportunities and guiding the deployment of resources" (Davis, Sun 2006). Sørensen (2012) integrates the different academic perspectives on Business Development tasks and processes with insights from senior business developers and venture capitalists from successful high-tech firms into one general construct. Following this research, Business Development is defined as:

$\square$ "The tasks and processes concerning analytical preparation of potential growth opportunities, the support and monitoring of the implementation of growth opportunities" (Sørensen 2012).

The move from general descriptions of Business Development towards an actual definition raises the level of abstraction, but also helps identify what Business Development is and what it is not. First, the above definition emphasizes the coordinating role of Business Development that supports the vertical and horizontal integration among other organizational functions (e.g. R\&D, production, marketing and intellectual property) as well as external partners. Second, Business Development operates normally within the constraints of the firm's corporate strategy. Strategy refers here to choices that are commitment-intensive and thus bind the firm to a course of action (Ghemawat 1991). For example, if the Board of 
Directors decide to invest millions of Euros in a new plant specialized in producing tennis rackets, then the firm is bound to produce rackets at least until the costs of the plant and the capital needed to produce the rackets are (hopefully) earned back with some dividend.

As such, Business Development's objective is, on one side, to prepare and evaluate new opportunities that are in line with the overall corporate strategy. This does not exclude the pursuit of business opportunities that may lead to the discovery of new innovation streams that could impact on the overall future strategy. In a sufficiently large and specialized organization, the latter would be handed over to the Strategy Development function.

Finally, there is a sharp distinction between the Business Development activities in the planning phase of a growth opportunity and in their implementation phase. Preparing for a growth opportunity's launch and supporting its implementation requires very different skills. In the planning phase, Business Development relieves senior management with a recurrent managerial challenge: too little time and resources to take informed decisions, and during implementation they try to mend the typical disconnect between the preparation of growth opportunities and their actual implementation (Penrose 1959; Hrebiniak 2005).

\subsection{Business Development: Structure, Process, Tasks and People}

Structure Among these few exceptions, Kind and Zu Knyphausen-Aufseß (2007) aimed at clarifying the role of Business Development in the biotech industry. They identified three levels of Business Development function configurations determining their level of implementation in the organization: implicit, established and institutionalized. In particular, Business Development is implicit when it lacks of any task description or planned effort, while is established when its relevance and mission are officially recognized within the company. Finally, institutionalized Business Development implies the establishment of an ad hoc organizational unit managed by one or more Business Development specialist. In more established firms, the Business Development function is typically organized as a staff function that refers to senior management, but also works closely with the line functions, such as R\&D, production and marketing/sales (Sørensen 2012).

Tasks and processes Kind and $\mathrm{Zu}$ Knyphausen-Aufseß also identified several tasks, processes and human resources issues related to Business Development. In their case studies, Business Development turns out to be a specific business function-performing the three following activities: 1) the identification of new business opportunities, through a screening of market information and networking activity; 2) evaluation of the most profitable opportunities, by analyzing potential partner profiles, market and financial evaluation and strategic fit with the company; 3) negotiation of terms and conditions and adaptability of internal resources to enable implementation. Adding to this, Sørensen (2012) sustains that in sufficiently large and specialized organizations the opportunity identification phase may be carried out by people outside the Business Development function, such as specialists from Research, Product Development or Marketing.

The Business Development manager's tasks usually vary according to the different phases of the Business Development process. Prior to a decision to pursue a particular growth opportunity, the business developer prepares a business plan - 
based on a sound business model - for senior management. Through a synergic business planning activity, Business Development managers compile and synthesize necessary data and do due diligence as input for the decision-makers. This process usually involves close collaboration with the specialist business functions for the retrieval of intelligence that must be integrated for the business model and business plan.

If the growth opportunity is considered worth pursuing, it is the business developer's task to supervise the implementation of the initiative. Because of the in-depth knowledge about the growth opportunity based on inputs from various business functions, the business developer is better able to support, for example, the legal department in the negotiation of the terms in a collaboration deal. As such, the Business Development function and its business developers are an inherently part of the critical coordination and integration aspect of the pursuit and implementation of growth opportunities.

People In the end, Business Development tasks and processes are only as good as the people performing them. Sørensen (2012) describes the good business developers as "integrating generalists". This means that the business developer are able to constructively integrate knowledge from various areas of specialization and refrain from favoring one functional specialization over the other. Growth opportunities' success rests often on the strength of the weakest link, rather than a well performed aspect of its entirety. In line with other scholars (Davis, Sun 2006; Austin 2008), Sørensen suggests operationally to employing people possessing:

- practical knowledgeable about the technology, product, customer values, and industry dynamics

- capability to think conceptually and abstract and not just 'closing deals'

- $\quad$ specialists knowledge from multiple business functions

- experience with both top management and with work in line-functions

In order to provide further direct insights on the well-organized Business Development function's structure, tasks and process, and people, we will now present and analyze three cases from the biotechnology industry.

\section{Methodology}

In order to explore the main elements underlying a Business Development capability, we chose an in-depth case study methodology. The analysis follows the data collection rules established by Eisenhardt (1989) and Yin (1994), and uses various information sources in the data gathering process (interviews and other secondary data). In order to obtain a clearer understanding of reality, we used a qualitative approach that draws the attention to processes, meaning of patterns and structural features (Flick et al. 2004). The value of a business opportunity depends on the industrial context in which a company operates (Andersson 2004), and it can also be assumed that the logics related to opportunity evaluation and preparation may be different across industries.

The focus of this study is on biotechnology. Biotechnology industry is a sciencebased industry, which covers a diverse range of fields, including therapeutics, agriculture and environment, industrial and ICT (Hine, Kapeleris 2006). It is a global industry which is also considered as entrepreneurial, innovative, rapidly 
changing, and knowledge-intensive (Brännback et al. 2007). In order to minimize the effects of environmental and situational factors typical of the overall biotech industry, we narrowed our focus on 'red biotech' firms (Ernst \&Young 2014), i.e. those companies that concentrate on the research and development of new drugs (product companies) and/or on the development of new technologies that help other companies in their research and development of new drugs (platform companies).

The selection of cases is a crucial decision in the research process and should therefore be made after careful consideration and a critical evaluation of the alternatives. Theoretical sampling is recommended (Eisenhardt, Graebner 2007); this implicates choosing cases that are expected to extend or replicate the developing theory (Eisenhardt 1989). In order to increase the explanatory power, cases have been selected keeping in mind their theoretical qualifications and to ensure a good fit with conceptual categories (Smith 1991; Eisenhardt 1989). Accordingly, we use the concept of 'theoretical sampling' (Eisenhardt 1989) and that differ significantly in their size, we selected three biotechnology companies that explicitly consider Business Development as a key process for gaining competitive advantage on competitors, sustained over time. In addition, following the logic of maximum variety (Cook, Campbell 1979), we included firms operating in different countries (U.S., Italy, France), of different size (ranging from 21 to 520 employees), active in diversified sectors (oncology, ophthalmology, metabolic disease) and involved in various value-adding activities (research, development, pre-clinical. commercialization, marketing, etc). Finally, we selected cases that could represent the entire range of business models: product, platform, or "hybrids" (Kind, Zu Knyphausen-Aufseß 2007).

This aspect of the case study design facilitated the generality of the findings in a wide spectrum of firms. See Table 1 for the main descriptives.

Table 1: Descriptives of the Three Biotech Cases

\begin{tabular}{|c|c|c|c|c|c|c|}
\hline $\begin{array}{c}\text { Company's } \\
\text { Name }\end{array}$ & $\begin{array}{c}\text { Home } \\
\text { country }\end{array}$ & $\begin{array}{c}\text { Year of } \\
\text { foundation }\end{array}$ & Employees & $\begin{array}{c}\text { Turnover } \\
\mathbf{( \$ )}\end{array}$ & $\begin{array}{c}\text { Therapeutic } \\
\text { focus }\end{array}$ & $\begin{array}{c}\text { Business } \\
\text { model }\end{array}$ \\
\hline $\begin{array}{c}\text { Crown } \\
\text { bioscience }\end{array}$ & U.S. & 2006 & 520 & $\$ 210$ mio & $\begin{array}{c}\text { Metabolic } \\
\text { disease }\end{array}$ & platform \\
\hline Congenia & Italy & 2004 & 21 & $\$ 0,3$ mio & Oncology & hybrid \\
\hline Nicox & France & 1996 & 43 & $\$ 6.8$ mio & Ophthalmology & product \\
\hline
\end{tabular}

\subsection{Crown Bioscience and its Business Development Process}

Founded in 2006, Crown Bioscience is a multinational drug discovery company providing cutting-edge translational platforms and cost-effective drug discovery solutions for its biotech and pharmaceutical partners in dedicated therapeutic areas: Oncology and Metabolic Disease.

Structure. Business Development at Crown Bioscience is carried out by four people, each assigned to a particular geographical area (Europe, China, Japan and USA). Business Development is organized as a staff function which gives the Business Development managers the power to coordinate resources from other linefunctions, such as R\&D and the intellectual property department. All four Business 
Development managers are fully dedicated to achieve Business Development goals, the evaluation of which is based partly on quantitative assessment of the deals closed, and partly on measurement of deals maintained over time. This practice relates to whether Business Development is purely a prospective functionality that looks for opportunities and brings opportunities in, or it is also responsible for the maintenance of relationships and of collaborations.

Process. In the past, the Business Development and the R\&D departments have had some major misunderstanding, mostly because of discontinuous communications and poor alignment on each other goals and priorities. That is why Crown Bioscience has set up very specific communication mechanisms, such as shared online blogs, through which each part keeps track on a regular basis of the most important activities. The Business Development process at Crown, in fact involves the identification of different kind of business opportunities that may turn into technology licensing deals, collaboration deals, partnerships with local companies to increase the local presence and M\&A activities, etc. Before starting the opportunity management process, these growth options are presented to CSO (Chief Scientific Officer) for approval; then the Business Development manager proceeds with the evaluation, due diligence, and final negotiation phase. Furthermore, Business Development goal is to provide to the CSO any relevant market info that the CEO and the Board may need for company growth. Since Business Development is responsible for creating the most suitable conditions for implementing the strategy, it is extremely important that the alignment with the top management is maintained through constant meetings and social exchanges.

People. Overall, Business Development people at Crown Bioscience are all relatively senior and respond directly to the CSO. All of them have both knowledge of science and management. In particular, the one responsible for the European area possesses a Bachelor of Science degree in Chemical Engineering and an MBA. He has several experiences in other biotech and pharmaceutical companies, a medical device firm and a medical equipment manufacturer. Thanks to his previous experiences, he has a wide business network that allows him to more easily capture new business opportunities emerging from the market.

\subsection{The Experience of Congenia}

Congenia spun out from a collaboration between the University of Milan and the European Institute of Oncology in 2004, and was soon after acquired by Genextra SpA. Congenia has since then been focused on developing small molecule drugs that target the mitochondrial permeability transition pore (mPTP), a protein channel with multiple macromolecular components which, together with another mitochondrial protein p66, appears to be associated with oxidative stress-induced cell death.

Congenia is one of the first pharmaceutical companies focused on targeting specifically the mPTP. Preclinical research indicates that this pathway plays important roles in multiple diseases, including myocardial infarction, stroke, neurodegenerative, cardiovascular, and metabolic diseases.

Structure. For Congenia, Business Development activities are the heart of the firm, along with R\&D. The company has one corporate Business Development manager, who is responsible for new opportunities identification. At Congenia, the 
Business Development role is considered of high responsibility, since the Business Development manager is the one who makes strategy happen. Accordingly, she has the power to 'rent' some resources with specific knowledge that can support her in the evaluation of a new potential project in which to invest, or in a partner's capability to perform particular technological operations. The evaluation of Business Development deals is consequently based on both quantitative and qualitative criteria. The quality of a deal is reflected by the quality - in terms of market power and share - of the partner. With regard to compensations, Business Development managers receive bonuses according to the number and conditions of deals closed. In addition, the company evaluates also the tacit information and data Business Developers detect during the scouting process, since they can positively influence future strategies and market evaluation.

Process. The Business Development process initiates researches, including scouting, analysis and evaluation of projects of interest to be acquired within the holding structure. In a second phase, once a project - or part of it - is selected and acquired, the Business Development manager starts scanning the environment again, to identify new opportunities that help develop the project itself. The final goal is to make it reach a level of maturity such that it can then be licensed-out or sold. The Business Development manager dedicates a lot of his time to attend conferences and industry specific events in different countries, where she can get updated information on the market and develop/maintain her business network.

People. The corporate Business Development manager has both business and scientific/technical background. She joined Congenia in May 2006 and has since then been involved in a number of activities ranging from evaluation of new investing opportunities to partnering, licensing as well as strategic development of other Genextra's subsidiary companies. With an MBA and a PhD in Biochemistry, the Business Development manager is also Chief Operating Officer and a member of the Board of Directors of two of the companies that Genextra controls. Before joining Congenia, she acquired experience in the technology transfer area in an American based life sciences technology commercialization firm, and before that with prestigious University's technology transfer office.

\subsection{Business Development Organization at Nicox}

Nicox S.A. is a global pharmaceutical company that was conceived in Italy (Milan) in 1996 by an Italian-American team with strong technical background and prior experience in the pharmaceutical industry. In line with its strategic repositioning in a new market space,

Structure. Due to the strong strategic relevance of Business Development in Nicox's business model, an ad-hoc organizational function was designed and implemented to better perform this activity. The choice to concentrate Business Development know-how within a specific business structure was driven by a very specific aim: to collect, store, integrate and diffuse significant Business Development-related knowledge within the organization. Such knowledge is gained through individual and organizational Business Development experience and constitutes a unique and firm-specific cradle of know-how. A multifunctional steering committee, composed by top management members, supervises Business Development activity and holds decision making power for the process. In 
particular, such entity decides whether to invest in a specific Business Development opportunity and to sign the contractual agreement. An efficient way to evaluate the Business Development manager is to link his pay to the number of deals he closes, but also to the value of those deals. In this way, the Business Development manager is motivated to pursue the most profitable opportunities for the firm that indirectly becomes the most profitable opportunities for himself.

Process. At Nicox the Business Development function provides the Board of Management, with two important types of information: first, the necessary data to evaluate the market, the competition, and the new emerging trends and, secondly, the quantitative and qualitative data on the probability of success of a new idea, project, venture, in line with the corporate strategy. This information becomes available through a systematic process of market scouting and analysis which is made effective by the capability of identifying appropriate business opportunities. The evaluation of information, resources and competences within and outside the firm may influence the Business Development manager in choosing one or another opportunity. In order to transfer the Business Development-related knowledge from the individual to the firm level, three important procedures are followed: constant relation, direct contact, and information sharing. Overall, Business Development at Nicox has a very important and strategic role not only for opportunity identification processes but also for strategy formation. The information that the Business Development manager gets from the market is in fact precious factors in the definition of the overall strategy.

People. The Business Development manager at Nicox is a member of the Board of Management (Executive Vice president), has a $\mathrm{PhD}$ in Chemistry and also a very rich experience in various management roles within other companies. Thanks to his background, he is able to understand science without necessarily being an expert in the opportunity sector related to a specific market segments; he must instead know how to cooperate and coordinate with experts inside the company at the right moment of the opportunity management process, i.e. evaluation and due diligence.

\section{Results and Discussion}

Current Business Development research is in its infancy and consequently our understanding of the Business Development concept remains unclear. The aims of this case study research are to clarify the unique aspects of Business Development per se as well as explore the specific organizational and managerial mechanisms underlie a Business Development capability.

\subsection{Structure}

Business Development was organized as a separate institutionalized function (Kind, Zu Knyphausen-Aufseß 2007) charged with the responsibility of pursuing and developing new business opportunities. The firms opted for a structural separation to avoid that Business Development efforts were overwhelmed by dayto-day activities and responsibilities related to other functions (R\&D, Legal department, etc.). Moreover, given the proactive nature of the searching phase, Business Development activity results to be very time consuming, thus calling for a 
dedicated staff taking care of it. The interviews with firms' managers proved that a dedicated unit with at least one full time professional proactively scanning external environment acted as an effective 'satellite' for identifying new opportunities and as a collector of knowledge. This constitutes a locus for learning in opportunity recognition (Zollo, Winter 2002) and, additionally, enhance external visibility and reliability as a point of contact.

Besides being an institutionalized organizational function, Business Development structure in the case study firms is characterized by staff powers that give it legitimacy to request part-time resources across divisions and high decisional autonomy to employ resources within its own budget. In particular, case study companies structured Business Development as a staff function to the CEO, or directly appoint a member of the board with Business Development responsibilities, in order to allow a more effective and efficient coordination with specialists from other functions as well as communication and updates with the top management. This is extremely important to ensure the alignment between strategy, opportunities, and their feasibility.

This type of organizational characteristic is in line with Sørensen's (2012) analysis of Business Development in big corporations, and become particularly important in the biotechnology industry, given the required specific scientific knowledge related to different opportunities. Furthermore, as suggested by the Congenia case, we can assert that staff organization of Business Development may also be effectively implemented and managed in smaller firms.

As explained in section 1, some authors see Business Development as a corporate entrepreneurial capability performed through a set of unstructured activities; its effectiveness is believed to depend mainly upon personal skills of entrepreneurs (Davis, Sun 2006, p. 148; Giglierano et al. 2011). In contrast - although personalspecific factors may contribute to better sensing and seizing of growth opportunities - our case studies demonstrate that additional structural factors are needed to capture the value of such opportunities.

In order to evaluate Business Development performance, the case study companies also set up particular incentive mechanisms that help to ensure the bond between Business Development people's goals and what is effectively the best growth opportunity for the firm. These mechanisms are, in fact, expressed in both qualitative and quantitative forms, in order to direct the motivation towards the pursuit of firm's objectives (Venkataraman 1997) and not only personal returns. Accordingly, the case study firms evaluate their Business Development managers not only in terms of opportunities captured and prepared, but also according to the sensibility and uniqueness of information they collect during the identification phase. Such information, very different from that which come out from classical market research, is tacit in nature, and may regard, for example, emerging trends in the innovation scenario, or a potential shift of a competitor's strategy.

\subsection{Process and Tasks}

High proficiency in executing tasks along the Business Development process helped the case study firms to identify new opportunities and organize effectively and efficiently to embrace them (Teece et al. 1997). From the analysis of the 
present biotechnology cases, four phases emerged to be critical in successfully pursuing opportunities: (proactive) search, evaluation, negotiation, and alliance management.

In a dynamic and science based industry like biotechnology, investments in the development of market knowledge base are often forgotten (Costa et al. 2004). This is why many small biotech firms have a poor commercial success. In order to overcome this shortcoming, the Business Development process in the biotechnology industry usually includes an initial systematic scanning phase. The latter is particularly central to detect unstable windows of opportunities and evaluate the external environment. In order to do that, Nicox and Congenia's pointed out the importance of managing a rich professional network: this may originate from personal contacts of Business Development managers and other members of the organization, along with various collaborators and partners, To facilitate the initiation, development and maintenance business relationships with other companies, Congenia, Nicox and Crown Bioscience' Business Development managers systematically visit industry-specific partnership events such as conferences and fairs. This allows a more effective identification of opportunities and help mitigate information asymmetries, reduce the risk of opportunistic behaviors facilitate the matching between supply and demand of opportunities.

In line with previous literature (Sørensen 2012; Kind, Zu Knyphausen-Aufseß 2007) the case study firms also highlights the importance of an accurate evaluation phase which consists, apart from disclosing more confidential information, of an in depth analysis of the potential partner and the opportunity, also known as 'due diligence'. Given the specificity of the scientific knowledge involved, this phase demand a very close collaboration between the R\&D department, the Intellectual Property unit and Business Development. At this point, in order to evaluate the economic and strategic potential of the opportunity, Business Development prepares business plans, as suggested by Sørensen (2012).

In the negotiation phase, the legal experts come to the scene and sustain Business Development people in the evaluation of the deal terms. This is a particularly sensible phase, where the top management may also be involved.

A fourth phase, alliance management, is particularly common in the present cases from the biopharmaceutical industry. After the opportunity has been prepared and seized, the relationship with the eventual partner must, in fact, be monitored and carefully managed. This approach ensures the best possible collaboration between the parties and creates a trusty environment that can constitute the bases for future additional agreements. In summary, while the three former phases correspond to those of Kind and Knyphausen-Aufseß (2007), the latter is a context-specific phase in situations where Business Development is performing alliance opportunities. This activity is also related to the business developers' role during the 'implementation' phase, as suggested by Sørensen (2012), where the business developer oversees the supervision of a particular collaboration and support in its development. Note that this activity may be performed by specialized alliance managers in larger organizations. 


\subsection{People}

Successful Business Development is accomplished through the work of individuals. In the case study firms, people responsible of carrying out Business Development must be skilled workers that integrated technical competences and managerial and analytical skills. Scientific background but also past experience in sales departments is the most common and effective mix, since knowledge of both products and managerial practices produced an effective blend of market and technological competencies. People that integration different sources of "general" expertise often cited as "integrating generalist" (Sørensen 2012) are a critical success factor in the context of Business Development, which is a knowledge intensive activity that requires the execution of heterogeneous tasks, ranging from scientific to management and legal.

In addition, a substantial coordination capability and team working abilities are necessary, because Business Development may involve the setting up of a team of complementary people with different skills and objectives. In the case study companies this team is called upon from other company's departments when needed. However, as suggested by Sørensen (2012), in larger organizations such team of resources may be dedicated to Business Development full time

Other industry specific traits that Nicox, Congenia and Crown Bioscience look for in their Business Development managers are risk tolerance, in order to tackle high degree of uncertainty often characterizing these initiatives; communication skills, to manage relationships both internally and externally; entrepreneurial attitude that would assemble and integrate resources to drive change. Figure 2 summarize the contribution of the case study analyses in light of the theoretical model presented Figure 1.

Therefore, a capability in Business Development emerges as a collective phenomenon, which allows the case study firms to effectively perform pursue their growth opportunities. In fact, this capability not only originates from the very talented individuals employed in the firm, but is enabled also by specific organizational and process solutions; these allow to ensure adequate direction, commitment and coordination so that potential individual capacities can convert into competitive advantage.

\section{Conclusions and Managerial Take Away}

The aim of the paper is to explore the foundations of a Business Development capability in the biotech industry on the basis of particular organizational structures, process and tasks, and people. We show that the Business Development construct meaningfully can be anchored in the dynamic capabilities theoretical framework. Following from this we infer that competitive advantage not only stems from valuable, rare and difficult-to-imitate resources and capabilities, but from how they are configured and organized by managers (Eisenhardt, Martin 2000; Teece et al. 1997; Teece 2007; Barney, Hesterly 2012). 
Figure 2: Main Elements of a Business Development Capability

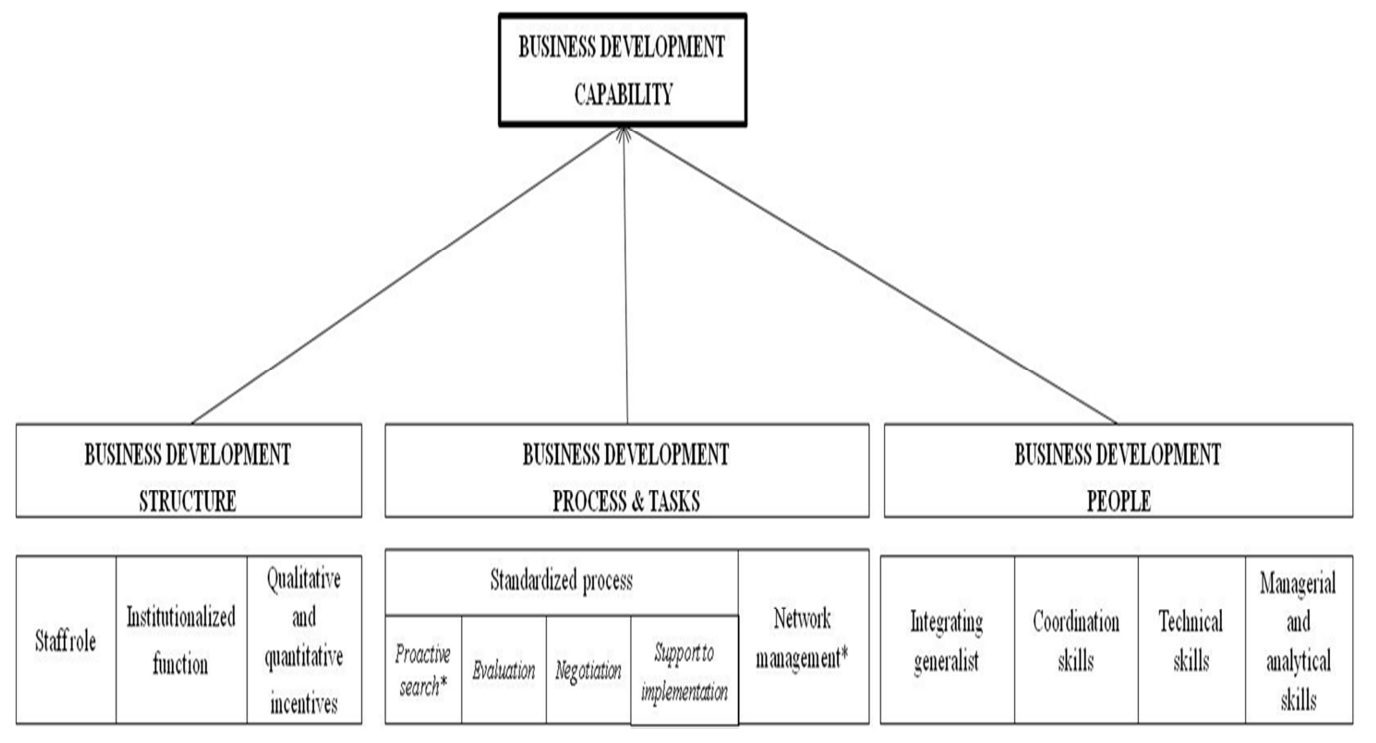

* Specific to the three cases. In sufficiently large and specialized firms, these activities are typically taken care of by technical specialists and alliance managers respectively

The findings of this study provides a strong foundation for firms willing to set up their own Business Development units to pursue growth opportunities more systematically or for firms who may have rudimentary Business Development activities, but need to make changes because of poorl performance. What we suggests should be considered as general advices and as starting points to be evaluated according to company needs and resources, rather than best practices or "how-to" plans for success. The choice of biotech firms is particularly interesting, since they seem more mature relative to other industries (see e.g. Kind, Knyphausen-Aufseß 2007) when it comes to implementing well-structured Business Development functions. Other industries can learn therefore benefit from them and the insights conveyed in this paper.

The Business Development functions and business developers explored in the three cases represent an approach to Business Development that naturally is constrained by their size and age. As the organizations become larger and more specialized, the Business Development tasks and processes as well as the business developers will become narrower in scope. For example, while a systematic search is an important task of the Business Development function in the context of cases presented here, growth opportunities may also be identified by, for example, Sales/Marketing managers, Product Development people, or the CEO; each having their own different planning processes and screening procedures (Sørensen 2012).

Business Development then analyzes and qualifies the selected growth opportunities further, coordinates resources for the Due Diligence, and then hand the decision to execute over to senior management. In large (30.000+ employees) biopharmaceutical, Business Development tasks would probably be much close to the 'evaluation' and 'negotiation' steps of the Business Development process reported in Figure 2. Business Development then supports and monitors the integration of the growth opportunity until it becomes business-as-usual and enters 
the firm's strategic budget (Sørensen, 2012). In the case of biotech Business Development, such implementation phase is substantially reflected in alliance management activities.

Finally, although the research results provide a useful framework for organizing and implementing a Business Development function within a firm, the study is qualitative in nature and thus calls for further empirical work on Business Development capability. Future researches should aim at exploring more in depth relationships between Business Development and competitive advantage throughout empirical studies on a large scale. To do so, a central point should be to track how firms develop Business Development capability over time.

In conclusion, the main managerial takeaway is to focus on the above described managerial and organizational structures, tasks and processes and people aiming at preparing for and support the implementation of growth opportunities rather than merely focus on 'Business Development' labeled activities. We acknowledge the wisdom to Shakespeare, who makes Juliet say:

\author{
$\square$ "What's in a name? that which we call a rose \\ By any other name would smell as sweet;" \\ (Romeo \& Juliet, Act II, Scene II)
}

\title{
Bibliography
}

Amit Raphael, Schoemaker Paul JH (1993) Strategic Assets and Organizational Rent. Strategic Management Journal, vol. 14, n. 1, pp. 33-46.

Austin Martin (2008) Business Development for the Biotechnology and Pharmaceutical Industry. Gower Publishing Limited.

Barney Jay (1991) Firm Resources and Sustained Competitive Advantage. Journal of Management, vol. 17, n. 1, pp. 99-120.

Barney Jay, Hesterly William .S. (2012) Strategic Management and Competitive Advantage: Concepts and Cases. 4.ed (Intl. edition). Upper Saddle River: Prentice-Hall.

Brondoni Silvio M. (2008) Market-Driven Management, Competitive Space and Global Networks. Symphonya. Emerging Issues in Management (symphonya.unimib.it), n. 1, pp. 14-27. http://dx.doi.org/10.4468/2008.1.02brondoni

Brondoni Silvio M. (2007) Management Consulting, Global Markets and Corporate Networking, Symphonya. Emerging Issues in Management (symphonya.unimib.it), n. 1, pp. 16-25. http://dx.doi.org/10.4468/2007.1.03brondoni

Burgelman Robert. A. (2002) Strategy as Vector and the Inertia of Coevolutionary Lock-in. Administrative Science Quarterly, vol. 47, n. 2, pp. 325-357.

Burgers J. Henry., Van Den Bosch Frans A. J., Volberda Henk. W. (2008) Why New Business Development Projects Fail: Coping with the Differences of Technological versus Market Knowledge. Long Range Planning, vol. 41, n.1, pp. 55-73.

Cook Thomas D., Campbell Donald.T. (1979) Quasi-Experimentation: Design and Analysis Issues for Field Settings. Chicago: Rand McNally.

Coriat Benjamin., Dosi Giovanni (2009) The Nature and Accumulation of Organizational Competences/Capabilities. Revista Brasileira de Inovação, vol. 1, n.2, pp. 275-326.

Costa Carla, Fonte, Margarida, Heitor Manuel V. A. (2004) A Methodological Approach to the Marketing Process in the Biotechnology-Based Companies. Industrial Marketing Management, vol. 33, n. 5, pp. 403-418. 
Davis Charles H., Sun Elaine (2006) Business Development Capabilities in Information Technology Smes in a Regional Economy: An Exploratory Study. Journal of Technology Transfer, vol. 31, n.1, pp. 145-161.

Day George S. (2011) Closing the Marketing Capabilities Gap. Journal of Marketing, vol. 75, n. 4, pp. 183-195.

Dosi Giovanni, Nelson Richard, Winter Sidney (2000) The Nature and Dynamics of Organizational Capabilities. Oxford University Press.

Doz Yves, Jose Santos, Peter J. Williamson. (2001) From Global To Metanational: How Companies Win in the Knowledge Economy. Cambridge: Harvard Business Press.

Eisenhardt Kathleen. M., Martin Jeffrey A. (2000) Dynamic Capabilities: What are they? Strategic Management Journal, vol. 21, pp. 1105-1121.

Eisenhardt Kathleen M., Santos Filipe M. (2002) Knowledge-Based View: A New Theory of Strategy. Handbook of Strategy and Management, pp. 139-164.

Ernst \& Young (2014) Italian Biotechnology Report. Report for Assobiotech

Giglierano Joseph, Vitale Robert, McClatchy JJ (2011) Business Development in the Early Stages of Commercializing Disruptive Innovation: Considering the Implications of Moore's Life Cycle Model and Christensen's Model Of Disruptive Innovation. Innovative Marketing, vol. 7, n.2, pp. 29-39.

Gnecchi Flavio (2009) Market-Driven Management, Market Space and Value Proposition. Symphonya. Emerging Issues in Management (symphonya.unimib.it), n. 2, pp. 33-45. http://dx.doi.org/10.4468/2009.2.04gnecchi

Jantunen Ari, Puumalainen Kaisu, Saarenketo Sami and Kylaheiko Kalevi (2005) Entrepreneurial Orientation, Dynamic Capabilities and International Performance. Journal of International Entrepreneurship, vol. 3, n. 3, pp. 223-243.

Kale Prashant, Dyer Jeffrey H., Singh Harbir (2002) Alliance Capability, Stock Market Response, and Long-Term Alliance Success: The Role of the Alliance Function. Strategic Management Journal, vol. 23, n. 8, pp. 747-767.

Kind Sonia, Knyphausen-Aufseß D. Zu. (2007) What is "Business Development"? - The Case of Biotechnology. Schmalenbach Business Review, vol. 59, n. 2, pp. 176-199.

Lambin Jean Jacques. (2008) Market-Driven Management: Marketing Strategico e Operativo. McGraw-Hill.

Lumpkin G. Tom, Dess Gregory G. (1996) Clarifying the Entrepreneurial Orientation Construct and Linking it to Performance. The Academy of Management Review, vol. 21, n. 1, pp. 135-172.

Malerba Franco, Luigi Orsenigo (2001) Innovation and Market Structure in the Dynamics of the Pharmaceutical Industry and Biotechnology: A History Friendly Model. Industrial and corporate change, vol. 11, n.4, pp. 667-703.

McGrath, Ruth. G. (2001) Exploratory Learning, Innovative Capacity and Managerial Oversight. The Academy of Management Journal, vol. 44, n. 1, pp. 118-131.

Noda Tomo, Bower Joseph L. (1996) Strategy Making as Iterated Processes of Resource Allocation. Strategic Management Journal, vol. 17, pp. 159-192.

Penrose Edith. T. (1959) The Theory of the Growth of the Firm. John Wiley and Sons.

Pisano Gary P. (2007) Science Business. Boston: Harvard Business School Press.

Sciarelli Mauro (2008) Resource-Based Theory and Market-Driven Management. Symphonya. Emerging Issues in Management (symphonya.unimib.it), vol. 2, pp. 66-80. http://dx.doi.org/10.4468/2008.2.06sciarelli

Sørensen, Hans E. (2012) Business Development: A Market-Oriented Perspective. John Wiley \& Sons, Ltd.

Sørensen, Hans E. (2013) Business Development. in The Palgrave Encyclopedia of Strategic Management, eds. David Teece and Mie Augier. Macmillan Publishers Ltd.

Teece David J. (2007) Explicating Dynamic Capabilities: The Nature and Microfoundations of (Sustainable) Enterprise Performance. Strategic Management Journal, vol. 28, n.13, pp. 13191350. 
Teece David J., Pisano Gary P., Shuen Amy (1997) Dynamic Capabilities and Strategic Management. Strategic Management Journal, vol. 18, n. 7, pp. 509-533.

Uittenbogaard Boaz, Broens Lute, Groen Aard J. (2005) Towards a Guideline for Design of a Corporate Entrepreneurship Function for Business Development in Medium-Sized Technology-Based Companies. Creativity and Innovation Management, vol. 14, n.3, pp. 258-271.

Vallini Carlo, Simoni Christian, Market-Driven Management as Entrepreneurial Approach, Symphonya. Emerging Issues in Management (symphonya.unimib.it), n. 1, 2009, pp. 26-39. http://dx.doi.org/10.4468/2009.1.03vallini.simoni

Wernerfelt Birger (1984) A Resource-Based View of the Firm. Strategic Management Journal, vol.5, n. 2, pp. 171-180.

Winter Sidney G. (2003) Understanding Dynamic Capabilities. Strategic Management Journal, vol. 24, n. 10, pp. 991-995. 